\title{
Assessment of Sal Seedlings and Herbaceous Flora in the Khairbar Plantation of Sarguja Forest Division, Chhattisgarh
}

\author{
R. SINHA, M.K. JHARIYA* and D.K. YADAV \\ Department of Farm Forestry, Sarguja University, Ambikapur- 497001 (C.G.), India. \\ http://dx.doi.org/10.12944/CWE.10.1.42
}

(Received: November 08, 2014; Accepted: January 10, 2015)

\begin{abstract}
In the present study an attempt has been made to evaluate the growth performance of sal seedlings and also assess the diversity of herbaceous flora in the Khairbar plantation of Sarguja forest division during the year 2013-14. Study reveals that there are prominent variations in the height of the seedlings in Khairbar plantation. The root shoot ratio of seedlings ranged between 0.31 to 0.74 . The total height of seedlings ranged from 24.00 to $90.00 \mathrm{~cm}$. The girth of individual seedling ranged between 4.00 and $12.00 \mathrm{~cm}$. The number of branches per seedling ranged between $4.00-17.00$. The average collar diameter of sal seedling was $1.96 \mathrm{~cm}$ and the sturdiness ranged from 15.09-42.86. Total of 27 herbaceous species comprising 15 families were encountered in the study area. The total density of the herb species was 776000 individuals ha ${ }^{-1}$ and the maximum density was recorded for Mellilotus alba (64000 individuals ha-1), while minimum for Achyranthus aspera, Malvastrum coromandelicum and Rumex dentatus (12000 individuals ha ${ }^{-1}$ for each, respectively). The Shannon index $\left(\mathrm{H}^{\prime}\right)$ of herbaceous species was 4.606 , Simpson index $(\mathrm{Cd})$ was 0.045 , Species richness $(\mathrm{d})$ was 1.917 and Equitability (e) was 1.397, respectively. It was observed that the growth performance of sal seedling in the Khairbar plantation site is quiet slow as compared to the other tropical species. It may also be due to the higher population of the herbaceous species. The herbaceous species compete with the sal species for the sharing of the resources for the growth and development. Microclimate and management aspects are the major concern for the good growth performance of the species in plantation sites.
\end{abstract}

Key words: Diversity, Herbaceous flora, Sal, Plantation, Shannon index.

\section{INTRODUCTION}

The herbaceous species varies greatly along with the different microclimate of the region $1,2,3$. Herb layer contributes substantial role and responds quickly to changes in the environmental conditions. In landscapes with significant topographic heterogeneity, herb layer composition and diversity vary with gradients of microclimate, soil moisture, soil fertility ${ }^{4}$ and different kind of anthropogenic pressures ${ }^{5,6,7}$. Herbaceous community also alters by natural and anthropogenic disturbances. Disturbances at low severity, such as surface fires, usually cause minor damage to overstory trees but mainly affects to herb layer directly by killing aboveground parts and indirectly by altering the forest floor and the availability of light, water and nutrients $3,5,7,8$.

In the present era, the scale of new forest establishment has increased considerably ${ }^{9,10,11,12}$. Herbaceous layer is essential component for increasing diversity of the region as well as it plays a substantial role in the nutrient cycling. On the other hand, the plantation of forest tree species are influenced mainly during the growth period initially by the invasion of undesirable species as well as luxuriant growth of weeds and/or herbaceous flora ${ }^{11}$. 
Therefore, it is essential to quantify the herbaceous flora and also to know about its impacts on growth parameter in the new plantation site. The findings of the present investigation will help the researcher, ecologist and foresters to work in the other region of plantation to evaluate the growth of new seedlings and associated herbaceous species. Therefore, the present study was undertaken to investigate growth performance of sal in plantation site and to assess the structure and diversity of herbaceous species.

\section{MATERIALS AND METHODS}

The present study was carried out at Khairbar plantation site (Fig. 1), Ambikapur in Sarguja forest division during the year 2013-2014. District Sarguja in the state of Chhattisgarh is very rich in natural vegetation and biological wealth ${ }^{11}$. It lies between $22^{\circ} 58^{\prime}$ to $23^{\circ} 49^{\prime} \mathrm{N}$ latitude and $81^{\circ} 33^{\prime}$ to $82^{\circ} 45^{\prime} \mathrm{E}$ longitude. The average elevation of the area varies from 600 meter and above. Geologically, the area is dominated by upper Gondwana rocks which are rich in coal deposits ${ }^{11}$. The highest mountain ranges of the region occupies the northern part of the district. The climate of the study area is dry tropical. The mean monthly temperature ranges between $15.34^{\circ} \mathrm{C}$ (January) and $31.54^{\circ} \mathrm{C}$ (May) and the mean annual temperature averages $23.31^{\circ} \mathrm{C}$. The average annual rainfall is $1161.42 \mathrm{~mm}$ (Fig. 2).

\section{Location Map of Study Area}

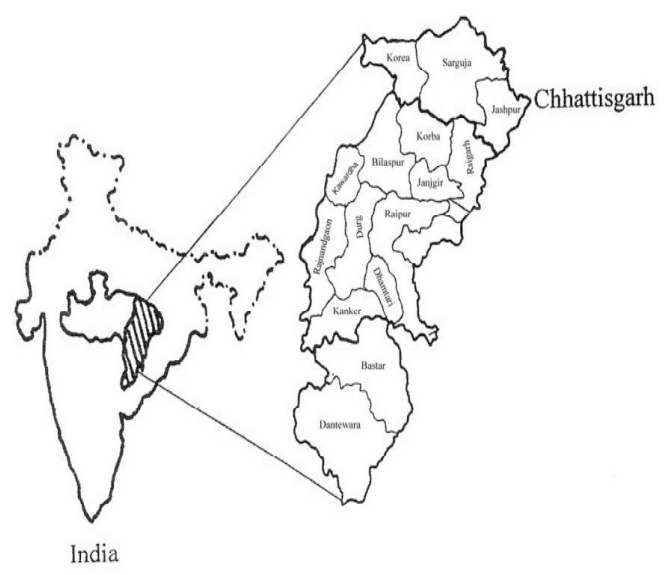

Sal plantation was established in the Khairbar beat, Ambikapur (Compartment No. 2581 and Coupe No. IX, Area 10 ha, range Ambikapur) in the year 2012; which is located in the north side of district headquarter. Ten seedlings were selected randomly from each part of the plantation area (viz, north, south, west, east and centre part ) for measuring various parameters viz., height, girth, total number of leaf, number of fresh leaf, number of defected leaf, leaf length and width, number of branch, collar diameter and sturdiness (the ratio of height to diameter). The growth parameters of sal seedlings was observed followed by Sinha et al. ${ }^{11}$, Kumar et al. ${ }^{9}$ and Bhagat et al. ${ }^{12}$.

The herbaceous vegetation was measured randomly by laying ten quadrats of size $50 \times 50 \mathrm{~cm}^{2}$. Vegetational data were quantitatively analysed for frequency, density and abundance ${ }^{13}$. The importance value index was calculated followed Phillips ${ }^{14}$. A/F ratio (Abundance to Frequency) for different species was determined by eliciting the distribution pattern. This ratio has indicated regular $(<0.025)$, random $(0.025-0.05)$ and contagious $(>0.05)$ distribution ${ }^{15,16}$. Species diversity for herb layers were determined using the Shannon-Weaver ${ }^{17}$ information function for species diversity. Concentration of dominance was measured following Simpson's ${ }^{18}$ index. Herbaceous vegetations were also measured for species richness $^{19}$, equitability ${ }^{20}$ and beta diversity ${ }^{21}$. The

Fig. 1: Location map of the study area

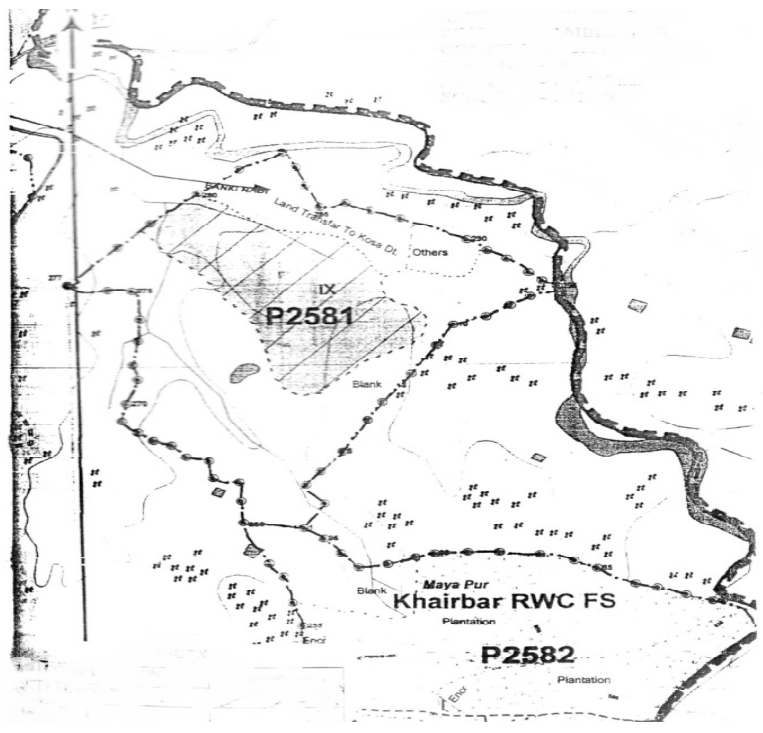


different parameters were calculated by following formula:

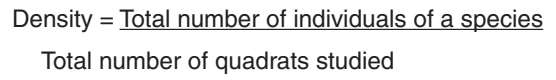

Frequency $(\%)=$ No. of quadrats in which species occurred $\times 100$ Total number of quadrats studied

Abundance $=\underline{\text { Total no of individuals of a species in all quadrats }}$ Number of quadrats in which the species occurred

The relative frequency, relative density and relative abundance, were calculated as following:

Relative frequency $=$ Frequency of the individual species $\times 100$ (RF) Total frequency of all the species

Relative density $(R D)=$ Density of the individual species $\times 100$ Total density of all species

Relative abundance $=$ Abundance of the individual species $\times 100$ (RA) Total abundance of all species

The Importance Value Index (IVI) was determined as :

Importance Value Index (IVI) $=\mathrm{RF}+\mathrm{RD}+\mathrm{RA}$.

\section{Species diversity analysis}

Species diversity was calculated as Where,$$
\mathrm{H}^{\prime}=-\mathrm{Pi} \log _{2} \mathrm{Pi}
$$

$\mathrm{Pi}$ is the proportion of total stand basal cover represented by the i species.

$$
H^{\prime}=3.3219\left[\log _{10} \mathrm{~N}-\left(\Sigma \mathrm{Ni} \log _{10} \mathrm{Ni} / \mathrm{N}\right)\right]
$$

Where,

Ni was the total basal cover of species i and $\mathrm{N}$ was the total basal area of all the species. The factor 3.3219 was used to convert the index value to $\log _{2}$

Concentration of dominance was measured as

$$
\mathrm{Cd}=\Sigma(\mathrm{Ni} / \mathrm{N})^{2}
$$

$\mathrm{Ni}$ and $\mathrm{N}$ were same as explained above.

Equitability (e) was calculated as

$\mathrm{e}=\mathrm{H}^{\prime} / \ln \mathrm{I}$.

$H^{\prime}=$ Shannon index and $S=$ the number of species.
Species richness was calculated as $\mathrm{D}=\mathrm{S}-1 / \ln \mathrm{N}$.

Where,

$\mathrm{S}=$ total number of species,

$\mathrm{N}=$ basal area of all species

Beta diversity was calculated as

$$
\beta d=\mathrm{Sc} / \overline{\mathrm{S}}
$$

Where

$\overline{\mathrm{S}} \mathrm{c}=$ total number of species in all sites and $\mathrm{S}=$ average species per site.

\section{RESULTS AND DISCUSSION}

The different parameters of sal seedlings measured in Khairbar plantation site is given in table 1. The growth of sal seedlings was found slower and it was found that only $10 \%$ of the planted seedlings were converted into the saplings. The total height of seedlings ranged from 24.00 to $90.00 \mathrm{~cm}$. The girth of individual seedlings ranged between 4.00 and $12.00 \mathrm{~cm}$. The average number of leaf per seedling was 48.10 , in which average defected leaf per seedling was 27.10 , while the mean healthy leaf per seedling was 21.00 , respectively. The infected leaf percent ranged from 38.14 to $90.91 \%$. The average leaf width of large leaf was $9.69 \mathrm{~cm}$ whereas it was $4.46 \mathrm{~cm}$ for the small leaf. The average leaf length of large and small leaf was $18.10 \mathrm{~cm}$ and $7.71 \mathrm{~cm}$, respectively. The number of branches per seedlings ranged from 4 to 17 . The average collar diameter of sal seedling was $1.96 \mathrm{~cm}$ and the sturdiness ranged from 15.09-42.86.

In the present study the sal seedlings showed slower growth as compared to the other species grown in tropical regions ${ }^{9,11,12}$. The site conditions and silvicultural management aspects are the key factors defining the good growth performance of the species in plantation sites. The optimum growth of any species in the plantation depends upon the species adoption and the site conditions like soil physical environment, soil texture, soil moisture, humous; nutrient availability and presence of microorganism etc., which can influence the establishment as well as root and shoot growth of the species $^{9,11,12,22,23,24,25,26}$. Since it is a departmental plantation carried out by the forest department, the management practices varied in 
comparison to the commercial plantation which is related mainly to economics. In order to maximize the survival and growth it is essential that proper care and management option should be opted ${ }^{11}$. Some practices like water management, weeding ${ }^{25}$ and silvicultural practices can boost up the growth of the seedlings.

\section{Structure and diversity of herbaceous species}

The data of herbaceous composition is given in table 2. A total of 27 herb species were recorded in the Khairbar plantation site. A total of 15 families were encountered in the Khairbar plantation site (Fig. 3). The herbaceous species comprises of Amaranthaceae (1), Apiaceae (1), Lamiaceae (1), Malvaceae (1), Oxalidaceae (1), Polygonaceae (1), Sapindaceae (1), Tiliaceae (1), Verbenaceae (1), Convolvulaceae (2), Cyperaceae (2), Euphorbiaceae (2), Asteraceae (3), Fabaceae (4) and Poaceae (5) families.

The total density of the herb species was 776000 individuals ha $^{-1}$ and the maximum density was recorded for Mellilotus alba (64000 individuals ha-1), while the minimum for Achyranthus aspera, Malvastrum coromandelicum and Rumex dentatus

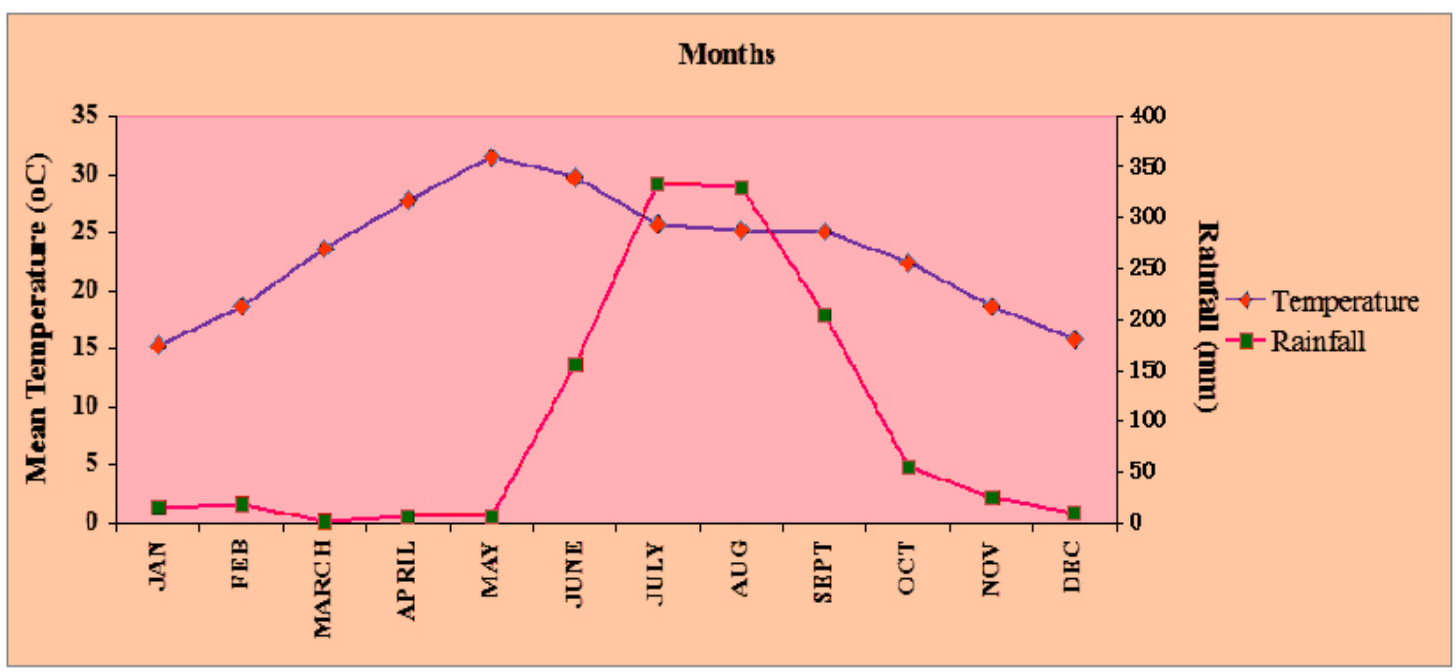

Fig. 2: Ombrothermic diagram for Sarguja district based on five years data (2009-2013)
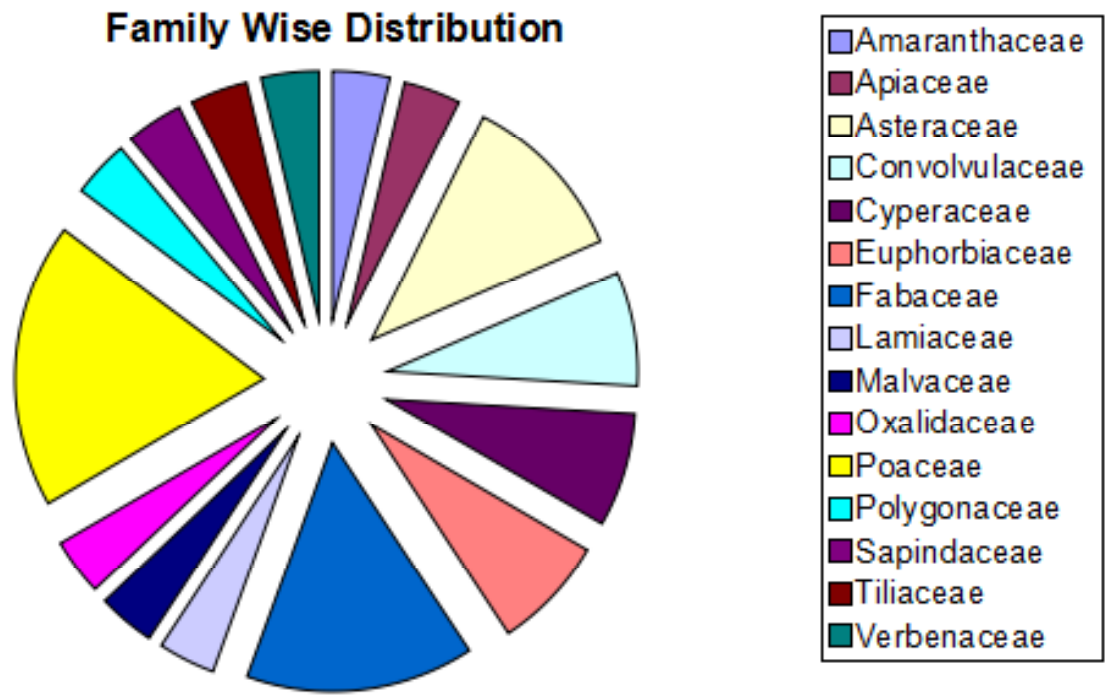

Fig. 3: Family wise distribution of herbaceous flora in Khairbar plantation site 
(12000 individuals ha-1 for each, respectively). The frequency of individual herbaceous species varied from $30-70 \%$. The Importance Value Index (IVI) of individual herb species ranged between 6.42-19.66, highest for Mellilotus alba and lowest for Rumex dentatus, respectively. A/F ratio (Abundance to Frequency) for different species was determined by eliciting the distribution pattern. This ratio of individual species ranged between 0.024 to 0.125 . It is evident from the data presented in the table 2, that Euphorbia hirta is only species which is showing the regular distribution pattern $(3.70 \%$ of the total) on the plantation site, whereas about $40.74 \%$ species were distributed randomly and about $55.56 \%$ of the recorded herbaceous species showing contagious type of distribution pattern. The diversity parameters of herbaceous species is presented in table 3 . The diversity parameters in the present study reveals that the Shannon index ( $\left.H^{\prime}\right)$ was 4.606, Simpson index (Cd) was 0.045, species richness (d) was 1.917, equitability (e) was 1.397 and beta diversity $(\beta d)$ was 1.00 , respectively.

The present study reveals higher number of herbaceous species as well as density in the plantation site. A total of 39 and 5-20 herbaceous species were reported by Oraon et al. ${ }^{27}$ and Jhariya et al..$^{5}$ in different sites of Kawardha forest division of Chhattisgarh. The reason for their maximum

Table 1: Performance of Sal species in Khairbar plantation site

\begin{tabular}{lccc}
\hline Parameters & Max. & Min. & Avg. \\
\hline Height (cm) & 90.00 & 24.00 & $57.55 \pm 2.72$ \\
Girth (cm) & 12.00 & 4.00 & $6.15 \pm 0.86$ \\
No. of Leaf & 97.00 & 9.00 & $48.10 \pm 3.55$ \\
DF Leaf & 50.00 & 6.00 & $27.10 \pm 2.54$ \\
Healthy Leaf & 60.00 & 1.00 & $21.00 \pm 3.68$ \\
IF Leaf \% & 90.91 & 38.14 & $61.18 \pm 2.37$ \\
Leaf Width (cm) & & & \\
Large (cm) & 13.00 & 4.00 & $9.69 \pm 0.74$ \\
Small (cm) & 6.00 & 2.00 & $4.46 \pm 0.55$ \\
Leaf Length (cm) & & & \\
Large (cm) & 22.00 & 13.00 & $18.10 \pm 0.74$ \\
Small (cm) & 9.00 & 4.00 & $7.71 \pm 0.53$ \\
No. of Branches & 17.00 & 4.00 & $8.90 \pm 1.47$ \\
Collar Dia. (cm) & 3.82 & 1.27 & $1.96 \pm 0.49$ \\
Sturdiness & 42.86 & 15.09 & $29.53 \pm 1.43$ \\
\hline
\end{tabular}

occurrence could be due to the availability of resources and other environmental factors ${ }^{5}$. Alhassan et al. ${ }^{28}$ reported the environmental factors as well as moisture level at site are responsible for the variation in species number, density and diversity. In the line of agreement in the present findings, Joshi and Bharti ${ }^{29}$ reported that plants may facilitate other plants directly by ameliorating harsh environmental conditions, altering substrate characteristics, or increasing the availability of a resource. Jhariya et al. ${ }^{5}$ have analysed the herbaceous vegetation in Bhoramdeo wildlife sanctuary, Kawardha district (C.G.) and reported total density varied from 112000668000 individuals ha- ${ }^{-1}$. Jhariya et al. ${ }^{6}$ reported that the density of herbs across various sites ranged from 502000 to 724000 individuals ha-1 in Rowghat of Narayanpur district (C.G.).

The distribution pattern of species depends upon the environment conditions and on the biological peculiarities. Abundance to frequency ratio used to assess the distribution pattern of species. In the present study it is found that most of the species were distributed contagiously and randomly, whereas a few species is distributed regularly. Likewise, Oraon et al. ${ }^{27}$, Jhariya et al. ${ }^{5,6}$, Kittur et al. ${ }^{7}$ and Jhariya $^{3}$ described that most of the species recorded the contagious and random distribution pattern whereas the regular distribution was found almost negligible or insignificant. Shadangi and $\mathrm{Nath}^{30}$ in his study also reported maximum species followed contagious distribution in the site. Odum ${ }^{31}$ stated that the most common distribution is contagious in natural condition and were performed due to small but significant variation in environmental conditions while random distribution was found only in very uniform environment.

The knowledge about species diversity is the vital parameter which typically defines the ecosystems and its functioning ${ }^{32}$. The diversity parameters of herbaceous species were close to values presented by Jhariya and Oraon ${ }^{2}$, which showed that the value of Shannon index in different sites ranged from 1.69-3.39, equitability 0.92 to 1.33 , species richness 0.33 to 1.48 , concentration of dominance 0.11 to 0.37 and beta diversity 1.50 to 3.80 of the herb layer in Kawardha. Jhariya et $a l .{ }^{6}$ have evaluated herbaceous vegetation in Rowghat (C.G.) and reported the Shannon index 
Table 2: Herbaceous composition in the Khairbar plantation site

\begin{tabular}{|c|c|c|c|c|c|}
\hline Species & D/ha & $\mathbf{F}$ & A & $A / F$ & IVI \\
\hline Achyranthus aspera $L$. & 12000 & 30 & 1.00 & 0.033 & 6.48 \\
\hline Apluda mutica $L$. & 16000 & 30 & 1.33 & 0.044 & 7.63 \\
\hline Biophytum reinnardtii Zucc. & 28000 & 30 & 2.33 & 0.078 & 11.07 \\
\hline Cassia tora $L$ & 40000 & 40 & 2.50 & 0.063 & 13.95 \\
\hline Corchorus capsularis L. & 20000 & 30 & 1.67 & 0.056 & 8.78 \\
\hline Coriandrum sativum $L$. & 28000 & 30 & 2.33 & 0.078 & 11.07 \\
\hline Cynodon dactylon L. & 56000 & 60 & 2.33 & 0.039 & 17.71 \\
\hline Cyperus rotundus $L$. & 40000 & 40 & 2.50 & 0.063 & 13.95 \\
\hline Dactyloctenium aegyptium $L$. & 44000 & 30 & 3.67 & 0.122 & 15.67 \\
\hline Desmodium pulchellum DC. & 32000 & 50 & 1.60 & 0.032 & 12.22 \\
\hline Dodonoea viscosa Linn. & 36000 & 50 & 1.80 & 0.036 & 13.11 \\
\hline Echinochloa crusgalli $L$. & 20000 & 30 & 1.67 & 0.056 & 8.78 \\
\hline Eragrostis tenella $L$. & 24000 & 30 & 2.00 & 0.067 & 9.93 \\
\hline Euphorbia geniculata Orteg. & 20000 & 30 & 1.67 & 0.056 & 8.78 \\
\hline Euphorbia hirta L. & 48000 & 70 & 1.71 & 0.024 & 16.52 \\
\hline Evolvulus nummularius $L$. & 20000 & 20 & 2.50 & 0.125 & 9.35 \\
\hline Fimbritylis dichotoma L. & 16000 & 30 & 1.33 & 0.044 & 7.63 \\
\hline Lantana camara Linn. & 24000 & 40 & 1.50 & 0.038 & 9.98 \\
\hline Malvastrum coromandelicum L. & 12000 & 30 & 1.00 & 0.033 & 6.48 \\
\hline Mellilotus alba Medikus & 64000 & 70 & 2.29 & 0.033 & 19.66 \\
\hline Merremia emarginata Burm.F. & 32000 & 40 & 2.00 & 0.050 & 11.97 \\
\hline Ocimum basilicum $L$. & 20000 & 30 & 1.67 & 0.056 & 8.78 \\
\hline Parthenium hysterophorus $L$. & 20000 & 20 & 2.50 & 0.125 & 9.35 \\
\hline Rumex dentatus $L$. & 12000 & 20 & 1.50 & 0.075 & 6.42 \\
\hline Tridex procumbence $L$. & 28000 & 30 & 2.33 & 0.078 & 11.07 \\
\hline Trifolium spp. $L$. & 44000 & 50 & 2.20 & 0.044 & 14.90 \\
\hline Xanthium strumarium $L$. & 20000 & 30 & 1.67 & 0.056 & 8.78 \\
\hline Total & 776000 & 990 & 52.60 & 1.601 & 300 \\
\hline
\end{tabular}

Table 3: Herbaceous diversity in the Khairbar plantation site

\begin{tabular}{ll}
\hline \multicolumn{2}{c}{ Diversity parameters } \\
\hline Shannon index (H') \\
Simpson's index (Cd) & 4.606 \\
Species richness (d) & 0.045 \\
Equitability $(\mathrm{e})$ & 1.917 \\
Beta diversity $(\beta \mathrm{d})$ & 1.397 \\
\hline
\end{tabular}

values ranged from 2.66 to 3.17 . The values of Simpson's index ranged from 0.14 and 0.23 , species richness from 0.67 to 1.06 and the equitability value $1.09-1.33$. The beta diversity values ranged from 2.40 to 3.60 . Shameem et al. ${ }^{33}$ reported the species diversity ranged between 1.80 to 3.03 . Concerning the species richness, a high number of species results with in higher community stability or rather resilience ${ }^{34}$. This takes the advantage of heterogeneity and increases their diversity. The level of heterogeneity created, obliviously would depend on the height and architecture tree species ${ }^{35}$. The species diversity range from 1.80 to 3.03 was also reported by Shameem et al. ${ }^{33}$ which are found to be similar with present study. Kittur et al. ${ }^{7}$ specified the diversity parameters of herb layer showed that Shannon index in different sites varied from 2.21. 2.57 , equitability from 1.02-1.24, species richness from 0.34-0.67, concentration of dominance from $0.21-0.31$ and beta diversity from 1.81-3.33 which 
are closer to the present study. These parameters were also supported by the findings made by Jhariya et al. ${ }^{5,6}$.

\section{CONCLUSION}

In the present study it was found that the growth of sal is quiet slow as compared to the other tropical species. The locality factors and management aspects are the major concern for the good growth performance of the species in plantation sites. The optimum growth depends upon the adoption of the species and the site conditions. Soil physical environment, soil texture, soil moisture, humus, nutrient availability and presence of microorganism etc can also influence the establishment as well as development of the species. Artificial application of ectomycorrhizal fungus synthesise mycorrhiza and helpful during initial growth period and for establishment of sal seedlings. In the present study the growth of sal seedlings is also affected due to the higher population of the herbaceous species. The herbaceous species compete with the sal for the sharing of the resources for the growth and development. Proper management practices should be applied for the betterment of the plantation site.

\section{REFERENCES}

1. Gilliam, F.S. and Roberts, M.R.: Conceptual framework for studies of the herbaceous layer. In: Gilliam FS, Roberts MR (eds) The herbaceous layer in forests of Eastern North America. Oxford University Press, Oxford, pp 3-11 (2003).

2. Jhariya, M.K. and Oraon, P.R.: Analysis of herbaceous diversity in fire affected areas of Bhoramdeo Wildlife Sanctuary, Chhattisgarh. The Bioscan, 7(2): 325-330 (2012b).

3. Jhariya, M.K.: Effect of forest fire on microbial biomass, storage and sequestration of carbon in a tropical deciduous forest of Chhattisgarh. Ph.D. Thesis, I.G.K.V., Raipur (C.G.), pp. 259 (2014).

4. Hutchinson, T.F., Boerner, R.E.J., Sutherland, S., Sutherland, E.K., Ortt, M. and Iverson, L.R.: Prescribed fire effects on the herbaceous layer of mixed-oak forests. Can J For Res, 35: 877-890 (2005).

5. Jhariya, M.K., Bargali, S.S., Swamy, S.L. and Kittur, B.: Vegetational Structure, Diversity and Fuel Load in Fire Affected Areas of Tropical Dry Deciduous Forests in Chhattisgarh. Vegetos, 25(1): 210-224 (2012).

6. Jhariya, M.K., Bargali, S.S., Swamy, S.L. and Oraon, P.R.: Herbaceous diversity in proposed mining area of Rowghat in Narayanpur District of Chhattisgarh, India. Journal of Plant Development Sciences, 5(4): 385-393 (2013).

7. Kittur, B.H., Swamy, S.L., Bargali, S.S. and Jhariya, M.K.: Wildland Fires and Moist
Deciduous Forests of Chhattisgarh, India: Divergent Component Assessment. Journal of Forestry Research, (DOI) 10.1007/s11676014-0471-0 (2014).

8. Knoepp, J.D., Elliott, K.J., Vose, J.M. and Clinton, B.D.: Effects of prescribed fire in mixed-oak forests of the Southern Appalachians: forest floor, soil, and soil solution nitrogen responses. J Torrey Bot Soc, 136: 380-391(2009).

9. Kumar, A., Dash, D. and Jhariya, M.K.: Impact of Rhizobium on Growth, Biomass accumulation and Nodulation in Dalbergia sissoo Seedlings. The Bioscan, 8(2): 553-560 (2013).

10. Kumar, A., Dash, D. and Jhariya, M.K.: Influence of Rhizobium Inoculation on $\mathrm{N}$, $\mathrm{P}$ and $\mathrm{K}$ Content in Dalbergia sissoo Roxb. Ecology, Environment and Conservation, 20(3): 1059-1065 (2014).

11. Sinha, R., Yadav, D.K. and Jhariya, M.K.: Growth performance of Sal in Mahamaya central forest nursery (Ambikapur), Chhattisgarh. International Journal of Scientific Research, 3(11): 246-248 (2014).

12. Bhagat, P.K., Dash, D., Raj, A. and Jhariya, M.K.: Effect of Rhizobium Inoculation on Growth and Biomass Accumulation in Leucaena Leucocephala. The Ecoscan (Special Issues) V: 65-74 (2014).

13. Curtis, J.T. and Mclntosh, R.P.: The interrelations of certain analytic and synthetic phytosociological characters. Ecology, 31: 
434-455 (1950).

14. Phillips, E.A.: Methods of Vegetation Study. Holt R and Winston New York USA. pp. 105 (1959).

15. Whiteford, P.B.: Distribution of woodland plants in relation to succession and colonal growth. Ecology, 30: 199-200 (1949).

16. Curtis, J.T. and Cotton, G.: Plant Ecology Workbook: Laboratory Field Reference Manual. Burgess Publishing Co., Minnesota. p. 193 (1956).

17. Shannon, C.E. and Weaver, W.: The Mathematical Theory of Communication. Urbana, USA: University of Illinois Press (1963).

18. Simpson, E.H.: Measurement of diversity. Nature, 163: 688 (1949).

19. Margalef, R.: Perspective in ecological theory. University of Chicago Press, Chicago, (1958).

20. Pielou, E.C.: Species diversity and pattern diversity in the study of ecological succession. J. Theor. Biol., 10: 370-383 (1966).

21. Whittaker, R.H.: Evolution and measurement of species diversity. Taxon, 21: 213-251 (1972).

22. Thakur, V., Khurana, D.K. and Thakur, I.K.: Effect of potting media on seed germination and seedling growth of Albizia lebbeck (Linn.) Benth. J. of Tree Sci., 19: 63-65 (2000).

23. Nandeshwar, D.L. and Parta, A.K.: Selection of proper potting mixture for production of Acacia catechu seedlings in the root trainers. Ind. J. of Trop. Biodiv., 12: $72-74$ (2004).

24. Lavania, S.K., Singh, V. and Singh, R.P.: Effect of growing media on seed germination and seedling quality in Himalayan Spruce (Picea smithiana) wall. Boiss.). Ind. J. of Forestry, 30: 211-214 (2007).

25. Bognounou, F., Thiombiano, A., Oden, P.C. and Guinko, S.: Seed provenance and latitudinal gradient effects on seed germination capacity and seedling establishment of five indigenous species in Burkina Faso. Tropical Ecology, 51: 207-220 (2010).

26. Pyasi, A., Soni, K.K. And Verma, R.K.: Effect of ectomycorrhizae on growth and establishment of sal (Shorea robusta) seedlings in central India. Nusantara Bioscience, 5(1): 44-49 (2013).

27. Oraon, P.R., Singh, L. and Jhariya, M.K.: Variation in herbaceous composition of dry tropics following anthropogenic disturbed environment. Current World Environment, 9(3): 967-979 (2014).

28. Alhassan, A.B., Chiroma, A.M. and Kundiri, A.M.: Properties and classification of soils of Kajimaram oasis of Northeast Nigeria. Int. J. Agric. Biol., 8: 256-261 (2006).

29. Joshi, B. and Bharti, M.C.: Temporal changes in facilitative effect of Coriaria nepalensis on growth of herbs on severely eroded hill slopes Central Himalaya. pp. 117-125. In: S.R. Gupta, N.K. Matta, A. Aggarwal, R.K. Kohli and A.K. Chawla (eds.) Ecology and Environmental Management: Issues and Research Needs. Bulletin of the National Institute of Ecology New Delhi \& Jaipur (2005).

30. Shadangi, D.K. and Nath, V.: Impact of seasons on ground flora under plantation and natural forest in Amarkantak. Ind. For., 131(2): 240-250 (2005.).

31. Odum, E.P.: Fundamental of Ecology. Saunders Co., Philadelphia (1971)

32. Scherer-Lorenzen, M., Korner, C. and Schulze, E.D.: Forest diversity and function: Temperate and boreal systems. Berlin, Springer. p. 399 (2005).

33. Shameem, S.A., Soni, P. and Bhat, G.A.: Comparative study of herb layer diversity in lower Dachigam National Park, Kashmir Himalaya, India. International J. Biodiversity and Conservation, 2(10): 308-315 (2010).

34. Guo, Q.: Early post-fire succession in California chaparral:Changes in diversity, density, cover and biomass. Ecol. Res., 16: 471-485 (2001).

35. Sagar, R., Singh, A. and Singh, J.S.: Differential effect of woody plant canopies on species composition and diversity of ground vegetation: a case study. Tropical Ecology, 49(2): 189-197 (2008). 